\title{
Isolation and Characterization of Essential Oil from Cymbopogon citrates Grown in Nepal
}

\author{
Shanta Pokhrel* and Sanjay Kumar Yadav \\ Department of Chemistry, Tri-Chandra Multiple Campus, Tribhuvan University, Kathmandu, Nepal \\ Email: shantabhattarai2014@gmail.com
}

\begin{abstract}
In this work essential oil was obtained by hydro-distillation from air dried leaves of Cymbopogon citrates using Clevenger apparatus and analyzed by Gas chromatography-mass spectrometry (GC-MS) technique. Twenty three chemical components were identified in the essential oil of Cymbopogan citratus leaves. Among them geranial (citral- $\alpha$ ) $32.51 \%$, neral (citral- $\beta$ ) $28.38 \%$ and myrcene $14.23 \%$ were found as major components. The preliminary phytochemical analysis of the methanolic extract of Cymbopogon citrates leaves showed that it has alkaloids, tannins, carbohydrates and flavonoids whereas negative results for phenols.
\end{abstract}

Keywords: Cymbopogon citrates, Essential oil, Citral- $\alpha$, Citral- $\beta, G C-M S$, Myrcene

\section{Introduction}

Plants having essential oils are significantly important in medical practice. The chemical composition of essential oil is complex and may contain hundreds of components. It is a mixture of fragrant volatile substances such as monoterpenes, sesquiterpenes, aromatic compounds, and their derivatives. Essential oils have been used as antimicrobial, anti-inflammatory, sedative, expectorants, and diaphoretics etc. There are numerous medicinal plants possess essential oils in their tissues such as sage (Salvia officinalis L.), eucalyptus species, peppermint (Mentha piperita L.), Scotch pine, elecampane (Inula helenium L.), linden (Tilia cordata Mill), garden heliotrope (Valeriana officinalis L.), etc ${ }^{1}$.

Lemongrass, Cymbopogon citratus, is a perennial medicinal plant belonging to family Geramineae, and it is distributed worldwide in tropical and subtropical areas of Asia, Africa, and America ${ }^{2-4}$. Some species (particularly Cymbopogan citratus) are commonly cultivated as culinary and medicinal herbs because of their scent resembling that of lemons (citrus lemon). Common names includes lemon grass, sarbed wire grass, silky heads, citronella grass, fever grass, tangled hierba or gavati chahapati among many others ${ }^{2}$.

Lemongrass is widely used as culinary herb in Asian cuisines and also as medicinal herb in India. It has a subtle citrus flavour and can be dried and powdered or used fresh. It is commonly used in teas, soups, and curries. It is also suitable for the use with poultry fish, beef and sea food. It is often used as a tea in African countries such as Togo, South Eastern Ghana Volta region and the democratic republic of

* Corresponding author 
Congo and latin American countries such as Mexico ${ }^{5}$. Lemongrass oil is used as pesticides and preservative. Research shows the lemongrass oil has antifungal properties. Despite its ability to repel some insects such as mosquitoes, its oil is commonly used as 'lure' to attract honey bees ${ }^{6}$.

Lemon grass Cymbopogan nardus and Cymbopogan winterianus grow to about $2 \mathrm{~m}(6.6 \mathrm{ft})$ and have magenta coloured base stems. These species are used in the production of soaps, insect repellant (especially mosquitoes) in insect sprays and candles and in aromatherapy. The principal chemical constituents i.e. geraniol and citronellol of citronella, are the antiseptics ${ }^{7}$. It is used as a pesticides and preservatives, is put on the ancient plant leaf manuscripts found in Nepal and India preservative ${ }^{8}$. It is also used as an addition to tea, and in preparations such as $\boldsymbol{k a d h a}$, which is a traditional herbal brew used against coughs, colds, etc. It has medicinal properties too and is used widely in ayurvedic medicine. It is supposed to help with relieving cough and nasal congestion. It shows antioxidant, anti-cancer properties and anti-inflammatory property ${ }^{9}$.

Herbal drugs have been used worldwide during the last few decades as evidenced by rapidly growing global and national markets of herbal drugs ${ }^{10}$. Several studies indicated that approximately $33 \%$ of drugs produced in the developed countries are derived from plants ${ }^{10}$. The present research was carried out to evaluate phytoconstituents of methanolic extract of Cymbopogan citrates leaves and investigate the composition of its extracted essential oil via Gas chromatography-mass spectrometry (GC-MS) technique.

\section{Experimental Methods}

\section{Materials and Sample Preparation}

The fresh leaves of Cymbopogon citratus were collected from the Nepal Agricultural Research Council Lalitpur, Nepal. Fresh and dried leaves of were subjected to hydro-distillation for $8 \mathrm{~h}$, using Clevenger type apparatus, according to method recommended by Guenther ${ }^{5}$. The extracted essential oils were dried with anhydrous sodium sulphate and stored in sealed cubet at low temperature before analysis. The extracted oil was analyzed by GC-MS using Varian 240 GC-MS system equipped with VF- 5 fused capillary column $(30 \mathrm{~m} \times 0.25 \mathrm{~mm}$, i.e. film thickness $0.25 \mu \mathrm{m})$; oven temperature was $50-180^{\circ} \mathrm{C}$ at a rate of $5{ }^{\circ} \mathrm{C} / \mathrm{min}$, transfer line temperature $250^{\circ} \mathrm{C}$, carrier gas was helium with a flow rate of $1 \mathrm{~mL} / \mathrm{min}$, split ratio 1:20, ionization energy $70 \mathrm{eV}$, and mass range 35-390 amu. The constituents of the oil were identified by comparison of their mass spectra with those of a computer library or with authentic compounds.

\section{Phytochemical screening}

For phytochemical screening, the plant samples were crushed and blended into into smaller pieces. $200 \mathrm{~g}$ of powdered Cymbopogon citratus samples (leaf) were taken into $2000 \mathrm{~mL}$ capacity conical flask. $1000 \mathrm{~mL}$ methanol was poured to the sample. The conical flask containing the mixtures was placed on a shaker for 24 hours and filtered the content through muslin cloth. The filtrate was then filtered again using suction pressure with the aid of a vacuum pump. The filtered extract was concentrated using the rotary evaporator equipment then dried on an evaporating dish at a temperature of $50-60{ }^{\circ} \mathrm{C}$ to a semisolid form. A sticky semi-solid greenish substance obtained which was subjected for phytochemical 


\section{J. Nepal Chem. Soc., Vol. 39, 2018}

screening using standard procedures ${ }^{11-14}$. The following qualitative tests for both the metabolites were done as follows:

\section{Test for alkaloids}

About $10 \mathrm{mg}$ of extract was taken and few drops of Wagner's reagent were added and the formation of a reddish brown precipitate indicates the presence of alkaloids.

\section{Test for Flavonoids}

Shinoda Test: $10 \mathrm{mg}$ of extract was added to pinch of magnesium turnings and 1-2 drops of concentrated hydrochloric acid was added. Formation of pink color indicates the presence of Flavanoids.

Lead acetate test: $10 \mathrm{mg}$ of extract was taken and few drops of 10\% lead acetate solution was added. Appearance of yellow colour precipitate indicates the presence of flavonoids.

\section{Test for Phenols and Tannins}

Lead acetate test: $10 \mathrm{mg}$ of extract was taken and $0.5 \mathrm{~mL}$ of $1 \%$ lead acetate solution was added and the formation of precipitate indicates the presence of tannins and phenolic compounds.

Ferric chloride test: Five mg of extract was taken and $0.5 \mathrm{~mL}$ of $5 \%$ ferric chloride was added. The development of dark bluish black color indicates the presence of tannins.

Sodium hydroxide test: Five mg of extract was dissolved in $0.5 \mathrm{ml}$ of $20 \%$ sulphuric acid solution. Followed by addition of few drops of aqueous sodium hydroxide solution, it turns blue which indicates the presence of phenols.

\section{Test for Carbohydrates}

Fehling's test: Five $\mathrm{ml}$ of Fehling's solution was added to $0.5 \mathrm{mg}$ of extract and boiled in a water bath. The formation of yellow or red precipitate indicates the presence of reducing power.

Benedict's test: Five $\mathrm{ml}$ of Benedict's solution was added to $0.5 \mathrm{mg}$ of extract and boiled in water bath. The appearance of red or yellow or green precipitate indicates the presence of reducing sugars.

\section{Results and Discussion}

A pale yellow essential oil with yields of $0.67 \%$ (on fresh weight basis) was obtained from fresh lemongrass plant. This result agrees with some works who reported that oil content of a normal cut should average $0.25-0.5 \%$, but with good management and selected strains could be yielded up to 0.66 $0.90 \%{ }^{15,16}$.

Twenty three components were identified in the essential oil of fresh air dried C. citratus leaves by different drying methods, which represented $100 \%$ of the oil components. The chemical constituents of oils are presented in Table 1. The components are listed in order of their retention time on the VF-5 column. 
Table 1: Essential oil components of Cymbopogan citratus

\begin{tabular}{|c|c|c|c|c|}
\hline Peak \# & R. Time & Area & Area $\%$ & Name \\
\hline 1 & 14.271 & 2179810 & 1.95 & Hept-5-en-2-one $<6$-methyl- $>$ \\
\hline 2 & 14.439 & 15880294 & 14.23 & Myrcene \\
\hline 3 & 16.693 & 862645 & 0.77 & Ocimene $<(Z)$-, beta- $>$ \\
\hline 4 & 17.192 & 375209 & 0.34 & Ocimene $<(\mathrm{E})$-, beta- $>$ \\
\hline 5 & 19.404 & 941462 & 0.84 & Linalool \\
\hline 6 & 19.594 & 1107383 & 0.99 & RT: 19.592 \\
\hline 7 & 19.711 & 2816978 & 2.52 & Sabinene hydrate $<$ trans- $>$ \\
\hline 8 & 20.485 & 202256 & 0.18 & Octa -2 , 4-dienol $<$ trans- $>$ \\
\hline 9 & 21.647 & 218224 & 0.20 & Thujone $<$ beta- $>$ \\
\hline 10 & 21.908 & 378737 & 0.34 & Nona-(2E,6Z)-dienal \\
\hline 11 & 22.165 & 400660 & 0.36 & Chrysanthemol $<$ trans- $>$ \\
\hline 12 & 22.859 & 1721067 & 1.54 & Verbenol $<$ trans- $>$ \\
\hline 13 & 23.392 & 2029535 & 1.82 & Rose furan oxide \\
\hline 14 & 23.722 & 2310227 & 2.07 & Isogeranial \\
\hline 15 & 23.891 & 1013333 & 0.91 & $\begin{array}{l}\text { Ethanol }<(2 Z)-(3,3- \\
\text { diementhylcyclohexylidene })->\end{array}$ \\
\hline 16 & 26.126 & 240743 & 0.22 & Oct-7-enol<3,7-dimethyl $>$ \\
\hline 17 & 26.548 & 31667250 & 28.38 & Neral \\
\hline 18 & 27.114 & 6499793 & 5.83 & Geraniol \\
\hline 19 & 27.934 & 38505521 & 34.52 & Geranial \\
\hline 20 & 30.916 & 257042 & 0.23 & Deca-(2E,4E)-dien-1-ol \\
\hline 21 & 32.499 & 282930 & 0.25 & Undec-(8Z)-enal \\
\hline 22 & 32.809 & 1456983 & 1.31 & Linalool isobutyrate \\
\hline 23 & 42.475 & $\begin{array}{c}224109 \\
\mathbf{1 1 1 5 7 2 1 9 1}\end{array}$ & $\begin{array}{c}0.20 \\
100.00\end{array}$ & Eudesmol <epi-gamma-> \\
\hline
\end{tabular}

The major components of the essential oils were geranial $(34.52 \%)$, neral $(28.38 \%)$ and myrcene $(14.23 \%)$ in oils extracted from air dried lemongrass leaves. The quality of lemongrass is generally determined by its citral content. Citral is a combination of bioactive isomers geranial and neral. According to Ref. ${ }^{17}$ the lemongrass essential oil is usually made up of citral at an average of 65 to $80 \%$.

This result showed 23 major components of the essential oil of lemongrass. Among 23 compounds, only 10 compounds (6-Methylhept-5-en-2-one, Myrcene, trans-Sabinene hydrate, trans-Verbenol, Rose furan oxide, Isogeranial, Neral, Geraniol, Geranial and Linalool isobutyrate) had a concentration of greater than $1 \%$. This is in agreement with several research work; reported the variations of 20 to $50 \%$ of 


\section{J. Nepal Chem. Soc., Vol. 39, 2018}

geranial and 30 to $40 \%$ of neral in lemongrass chemical composition ${ }^{15,18-20}$. According to Schaneberg and Khan, the essential oil of lemongrass contains mainly geranial and neral ${ }^{21}$. Other isolated components, such as $\beta$-myrcene, ocimene, $\beta$-cimene, linalool, citronellal, citronellol, caryophyllene and $\beta$-pinene, were present as minor components reported in $\operatorname{Ref}^{22}$.

Table 2 shows the phytochemical constituents of methanolic extract of lemongrass leaf. The result shows the presence of alkaloids, tannin, flavonoids and carbohydrate whereas phenol is absent. This agrees with the findings of Umar et al. ${ }^{10}$ and Aina et al. ${ }^{23}$.

Table 2: Phytochemical constituents of Cymbopogon citrates leaf

\begin{tabular}{|c|c|}
\hline Phytochemical Constituents & Leaf extract (methanol) \\
\hline alkaloids & + \\
Tannin & + \\
\hline Flavonoids & + \\
\hline Phenol & - \\
\hline Carbohydrate & + \\
\hline
\end{tabular}

\section{Conclusions}

The essential oil was successfully extracted from the plant Cymbopogon citratus by means of hydrodistillation method via clevenger type apparatus. The volatile constituents which is present in this plant was analyzed by the Gas Chromatography-Mass Spectroscopy. Twenty three chemical components were identified in the essential oil of Cymbopogan citratus leaves and dried citrus leaves obtained by GCMS technique including geranial (citral- $\alpha$ ) $32.51 \%$, neral (citral- $\beta$ ) $28.38 \%$ and myrcene $14.23 \%$ as a major component. The result of phytochemical screening of methanolic extract of Cymbopogon citratus leaves showed the presence of tannins, flavonoids and carbohyydrates whereas phenol is absent.

\section{Acknowledgements}

We would like to acknowledge Department of Plant Resources, Thapathali, Kathmandu, Nepal for GC-MS analysis. The authors gratefully acknowledged the Department of Chemistry, Tri-Chandra Multiple Campus, Tribhuvan University, Kathmandu, Nepal for providing available facilities to conduct this work.

\section{References}

1. W. S. Soliman, S. Salaheldin, H. M. Amer, International Journal of Scientific \& Engineering Research, 2017, 8, 630.

2. A. Akhila, CRC Press, Taylor and Francis group, 2010, 12, 108.

3. V. Francisco, A. Figueirinha, B. M. Neves, C. García-Rodríguez, M. C. Lopes, M. T. Cruz, M. T. Batista, Journal of Ethnopharmacology, 2011, 133, 818. 
4. S. Chanthal, S. Prachakoli, C. Ruangviriyachai, Journal of the Association of Official Analytical Chemists, 2012, 95, 763.

6. E. Guenther. In: The essential oils, D. Van Nostrad Company, Inc., New York, USA, 1950, IV, 20.

7. O. Koul, S. Walia, G. S. Dhaliwal, Biopesticides International, 2008, 4, 63.

8. M. Mc Guffin, C. Hobbs, R. Upton, American Herbal Products Association Botanical Safety Handbook, Boca Raton: CRC press; 1997.

9. J. C. Matasyoh, I. N. Wagara, J. L. Nakavuma, A. M. Kibural, African Journal of Food Science, $2011,5,138$.

10. M. Sharma, A. Gupta, R. Prasad, International Journal of Research and Review, 2017, 4, 103.

11. M. Umar, I. B. Mohammed, J. O. Oko, I. Y. Tafinta, A. A. Aliko, D. Y. Jobbi, Journal of Complementary and Alternative Medical Research, 2016, 1, 1. DOI: 10.9734/JOCAMR/2016/26783

12. J. B. Horbone, In: Phytochemical methods, $2^{\text {nd }}$ edition. Chapman and Hall, New York, 1984.

13. C. K. Kokate, A. P. Purohit, S. B. Gokhale, In: Pharmacognosy, $3^{\text {rd }}$ edition. Niralin Prakashan, Pune, 1995.

14. T. S. Geetha, N. Geetha, International Journal of PharmTech Research, 2014, 6, 521.

15. R. M. Shrestha, S. Pokhrel, R. N. Jha, Heritage Publishers and Distributers Pvt. Ltd., Kathmandu, Nepal, 2018, 67.

16. E. A. Weiss, Lemongrass. In Weiss E. A. (Eds.) Essential oil crops. Cambridge University Press, Cambridge, 1997, 86.

17. S. Maiti, S. Raju, K. Geetha, K. Mandal, National Research Centre for Medicinal and Aromatic Plants, Boriavi, Anand-387310, Gujrat, India, 2006, 16.

18. E. V. G. Nair, Cultiv. Util. Med. Aromatic Plants, 1977, 204.

19. A. K. Pandey, M. K. Rai, D. Acharya, Pharmaceutical Biology, 2003, 41, 421.

20. S. C. Nath, B. N. Saha, D. N. Bordoloi, R. K. Mathur, P. A. Leclercq, Journal of Essential Oil Research, 1994, 6, 85.

21. K. S. Chandrashekar, A. B. Joshi, Journal of Saudi Chemical Society, 2006, 10, 109.

22. B. T. Schaneberg, I. A. Khan, Journal of Agricultural and Food Chemistry, 2002, 50, 1345.

23. R. C. Torres, A. G. Ragodio, The Philippine Journal of Science, 1996, 125, 147.

24. V. O. Aina, M. B. Ibrahim, A. A. J. Adewumi, M. S. Abdulsalami, A. Godwin, S. Abdullahi, Journal of Pharmaceutical and Allied Sciences, 2014, 11, 2142. 